\title{
Using ISM-fuzzy MICMAC method: Develop enablers' framework of sustainable supply chain management in textile sector
}

\author{
*Ashish Patel ${ }^{1}$, Dr.Tushar N Desai ${ }^{2}$ Dr.Anjana $\mathbf{R}^{3}$ \\ ${ }^{1}$ Research scholar in the Department of Mechanical Engineering, SVNIT, Surat, India \\ ${ }^{2}$ Professor in the Department of Mechanical Engineering, SVNIT, Surat, India \\ ${ }^{3}$ Professor in the Department of Electrical Engineering, laxmi institute of technology, Sarigam, India \\ *Email: ashish.lit@laxmi.edu.in
}

DOI : 10.36909/jer.ICETET.15003

\begin{abstract}
The assembling area has contributed altogether to construction the country's financial system for agricultural nations similar to India; however it have likewise made numerous ecological and cultural issues. The arrangement with these issues, the current examination has recognized the empowering influences and displayed their interrelationships for the situation association of IndianThe aim of this paper is to identify and create relations between Sustainable Supply Chain Management Enablers (SSCMEs), to comprehend common impacts of these SSCMEs on SSCM use, and to discover the driving and reliance strength of SSCMEs. This paper has recognized 20 SSCMEs based on review and the sentiments of specialists from the scholarly community and industry. A nation poll-based study has been led to rank these recognized SSCMEs. The results of the study and interpretive basic demonstrating (ISM) strategy have been connected to develop shared connections among SSCMEs, which uncovers the immediate and aberrant impacts of each SSCMEs. The consequences of the ISM are utilized to contribute to the fluffy MICMAC (Matriced' Impacts Cruise's Multiplication Applique ea' un Classement) examination, to recognize the driving and the reliance intensity of SSCMEs. The 20 SSCMEs out of 25 SSCMEs (Mean $\geq 3.00$ ) have been considered for investigation through an acrossthe-country poll that reviews Indian car associations. The coordinated methodology is produced since the ISM show gives just a twofold relationship among SSCMEs. In contrast, fluffy MICMAC examination gives detailed investigation identified with driving and the reliance intensity of SSCMEs. The weighting for ISM show improvement and fluffy MICMAC is based on the opinions of a few industry experts. It is the most emotional decision, and many biases on the part of the judge can have an effect on the final result.The examination gives vital rules to the two professionals, just as the academicians. The professionals need focus on these SSCMEs all the more cautiously amid SSCM execution. SSCM administrators may deliberately design its long-haul development to meet the SSCM activity plan. While, academicians might be urged to classify diverse issues, which are huge intending to these SSCMEs. The course of action of SSCMEs in a progression, the classification into the enablers and ward classifications, and fluffy MICMAC are a selective exertion in the territory of SSCM usage.
\end{abstract}

Key words: Sustainable Supply Chain Management (SSCM), SSCM Enablers, survey, ISM, fuzzy MICMAC et 


\section{INTRODUCTION}

Reasonable store network the executives (SSCM) can be comprehended as the coordination of supportable advancement and production network. Practical improvement is frequently portrayed as containing three measurements - incorporating natural, societal and monetary issues for human progress likewise influences the corporate technique and activity. Although the ground of SSCM is measured very new, enthusiasm for SSCM has been becoming quickly throughout the years. Seuring and Martin (2008) acknowledged and evaluated 191 papers and originated the financial and natural parts of the production network are by a long shot the measurements that are the most concentrated along with the documents surveyed (73.3\%), and that papers incorporating maintainable measures just began to show up since 2002 onwards. Sikdar (2003), who takes a "large scale perspective", which contains the social, ecological, and monetary viewpoints, defined maintainability as "a shrewd parity among financial improvement, natural assets, and social value". Audits of various components identified with store network maintainability recommend that SSCM be connected to green structure, stock administration, creation arranging and control for remanufacturing, item recuperation, turn around coordination's, squander the executives, vitality use and discharges decrease (Ramudhin, Chaabane and Paquet, 2010).

SSCM is additionally considered as the key, straightforward reconciliation and accomplishment of an association's social, natural, and financial objectives through the foundational coordination of access between traditional business forms for enhancing the long haul monetary execution of the individual organization and its store network. (Wittstruck and Teuteberg, 2012) planned the residence of Sustainable Supply Chain", based on the three components of the Triple base procession, which are seen as the key columns essential to keep the working in equalization through hazard and consistence the executives shape the building's establishment. SSCM also requires the foundation of qualities and morals through the association, an efficient and adaptable "green" IT condition just as the arrangement of corporate methodology concentrates on maintainable improvement.

This examination begins with the intention to investigate the interdependency of the enablers of SSCM and how firmly they impact the execution of SSCM in the whole framework. Henceforth, it is critical to choose the proper arrangement of enablers and, after that, discover the connections among them. Be that as it may, the quantity of collaborations inside enablers, mainly when the portion of enablers is high, makes the mapping between the enablers confounded. To accomplish the best progressive structure, the incorporated ISM-Fuzzy MICMAC approach is utilized. It will prompt decrease the multifaceted nature and discover the effect of the chose enablers towards fruitful SSCM execution.

\section{Goal of the current study}

- To get out the important enablers to assist sustainable supply chain management implementation.

- To build up a pecking order a model of the enablers' structural structure assist SSCM implementation.

- To analyze the command of driving and reliance of the preferred enablers in SSCM.

- To talk about hypothetical and decision-making implication of the current study in SSCM.

The current examination has used ISM to build up a progressive system primary model of SSCM empowering influences in the Indian setting. The developed model is approved using the Fuzzy MICMAC method. To emphasise the unwavering consistency of the test's results, the new 
examination has included a fluffy scale in the MICMAC inquiry. The goal of ebb and flow research is to encourage specialists and academic scientists to recognise the interrelationships among SSCM empowering agents and to discern their driving and reliance strength. The present study is a case study of how the ISM and Fuzzy MICMAC approaches were used in one Indian assembly company.

The current investigation has distinguished 25 empowering influences of reasonable assembling through writing audit and assessments of specialists. Interpretive Structural Modelling (ISM) have be used to build up a progressive system primary model addressing the interrelationships among the empowering agents. The fluffy idea has been coordinated with the Matrix Impact of Cross Multiplication Applied to Classification (MICMAC) procedure to figure the driving/reliance force of the empowering agents. The current examination features "Restriction of conventional cycles" and "Public pressing factor" as the main empowering influences for reasonable assembling selection. The current examination talks about a case utilization of distinguishing the interrelationships and impact of maintainable assembling empowering influences. The current investigation gives essential references to analysts, experts, and strategy creators by investigating the empowering agents' interrelationships and driving/reliance power. The discoveries may energize the specialists and professionals to start similar investigations in other assembling associations by expanding empowering agents and ordering them into some more sensible gatherings.

\section{LITERATURE SURVEY}

The monetary development of agricultural nations can be limited by the issues talked about SSCM. The assembling area of non-industrial nations needs to receive inventive techniques to improve their ecological exhibitions. SSCM is one such innovative procedure that improves environmental exhibitions (Wu and Pagell, 2011). According to (US Department of Commerce and of, 2011), SSCMM is "the making of made items which use measures that limit negative ecological effects, preserve energy and regular assets, are ok for representatives, networks, buyers and are monetarily stable."

\section{Sustainable production enablers}

As previously stated, empowering agents are the most impacting factors that put the state's businesses to embrace SSCM prepare effectively. When the empowering agents are related to their impact of significance, it turns out to be simple for industry experts to use them for the selection interaction. The various perspectives and sentiments on SSCM empowering agents have been examined beneath:

Numerous NGOs and associations propel associations to contribute toward corporate natural and social obligations. Yadav et al., (2019) thought about corporate biological and social obligations as basic empowering influences for the selection of naturally defensive practices. Amindoust et al., (2012) featured that administration advancements and guidelines have a generous impact in receiving maintainability in the assembling area through law requirement and legal standards. Dhull and Narwal (2018) expressed to focal and condition unofficial laws and enactment have the main impact in receiving the economical practices approved by Malviya and Kant, (2014). Mani et al. (2015) featured a conflicting outcome for community manageability and showed with the purpose of administration guidelines lastly affect starting maintainability.

Notwithstanding the abovementioned, Carter and Jennings, (2002) likewise talked about good warehousing, which incorporates exercises, for example, terminal and stockroom area, appropriate putting away and discarding hazardous materials, gift of overabundance or outdated stock to 
neighbourhood networks, and preparing to work forklifts securely. The feasible covering was introduced by Parlak et al.,(2012) as bundling that increases the value of society by successfully containing and securing items amid development over the production network; is intended to utilize materials and vitality efficiently; is comprised of materials that are reused consistently and do not represent any dangers to human wellbeing or environments. Another supportable inventory network practice is Reverse Logistics; De Brito (2003) measured turnaround logistics as a procedure that ensures the utilization and reuse (efficiently and successfully) of the esteem put into items.

Usage of SSCM isn't constrained to assembling divisions as different creators Wilhelm et al., (2016) ; Chaplin and O'Rourke, (2014); Chiarini,(2012); Delgado et al.,(2010); Jin et al.,(2008); Koning et al.,(2008); Laureani et al., (2010)) have appeared of SSCM in budgetary, construction, medicinal services, benefit, and instructive parts too. Different contextual analyses (Kanigolla et al., (2014); Lertwattanapongchai and William Swierczek,(2014); Martinez and Gitlow,(2011); Nicoletti and Vergata,(2013); Sarkar et al., (2013); Thomas et al., (2009); Yi, (2012)) saw in writing notice profitability enhancement and benefits picked up by the association through execution of SSCM.

Table 1- Enablers of SSCM identified through literature review

\begin{tabular}{|c|c|c|}
\hline $\begin{array}{l}\text { SR. } \\
\text { NO }\end{array}$ & Enablers of SSCM & Literature Support \\
\hline 1 & Maintainable organizational culture & $\begin{array}{l}\text { (Li et al., 2006); (Cai et al., 2009); Kuik et } \\
\text { al.,(2010);(Zhu, Sarkis and Lai, 2012). }\end{array}$ \\
\hline 2 & Healthiness and safety issues & $\begin{array}{l}\text { (Carter and Rogers, 2008);(Carter and Easton, } \\
\text { 2011); (Carter et al., (2010). }\end{array}$ \\
\hline 3 & Natural product design & $\begin{array}{l}\text { (Bai and Sarkis, 2014); (Tay et al., 2015); (Uysal } \\
\text { and Tosun, 2014). }\end{array}$ \\
\hline 4 & Appropriation of wellbeing norms & $\begin{array}{l}\text { (Carter and Rogers, 2008); (Zaabi, Dhaheri and } \\
\text { Diabat, 2013);(Carter et al., (2010). }\end{array}$ \\
\hline 5 & Green purchase & $\begin{array}{l}\text { (Bai and Sarkis, 2014);(Sarkis, 2012);(Torfi, } \\
\text { Farahani and Rezapour, 2010). }\end{array}$ \\
\hline 6 & Reception of green practice & $\begin{array}{l}\text { (Bai } \text { et al., 2012);(Sarkis, 2012);(Fayet and } \\
\text { Vermeulen, 2014). }\end{array}$ \\
\hline 7 & Linking SSCM to customers & $\begin{array}{l}\text { (Zhuang, Xu and Cai, 2014);(Boyer and Hult, } \\
\text { 2005);(Chonticha Mathuramaytha, 2011). }\end{array}$ \\
\hline 8 & $\begin{array}{l}\text { Aligning government sustainability } \\
\text { approaches with the framework }\end{array}$ & $\begin{array}{l}\text { (Beikkhakhian et al., 2015);(Meneghetti and } \\
\text { Monti, 2015); (Walker and Jones, 2012). }\end{array}$ \\
\hline 9 & Benchmarking method & (Qin et al., 2016); (Cochran and Roche, 2009). \\
\hline 10 & Client fulfillment & (Faisal,2010); (Chan et al., 2014). \\
\hline 11 & Management engagement & (Carter and Roger, 2008);(Bouchery et al., 2012). \\
\hline 12 & $\begin{array}{l}\text { Financial contribution to infrastructural } \\
\text { expansion }\end{array}$ & $\begin{array}{l}\text { (Kudla and Klaas-Wissing, 2012a); (Croom, } \\
\text { Romano and Giannakis, 2000). }\end{array}$ \\
\hline 13 & Strategic planning & $\begin{array}{l}\text { (Kudla and Klaas-Wissing, 2012b);(Hussain, } \\
\text { 2011) }\end{array}$ \\
\hline 14 & Information sharing & $\begin{array}{l}\text { (Uștu, 2014);(Li et al., 2006); (Tajbakhsh and } \\
\text { Hassini, 2015). }\end{array}$ \\
\hline 15 & Powerful correspondence & $\begin{array}{l}\text { (Luthra, Garg and Haleem, 2014);(Gijo and } \\
\text { Antony, 2014); (Dubey, Gunasekaran and Childe, } \\
\text { 2015); (Wittstruck and Teuteberg,2012). }\end{array}$ \\
\hline 16 & SSCM venture following and checking & $\begin{array}{l}\text { (Sajjad, Eweje and Tappin, 2015); (Tay et al., } \\
\text { 2015); (Zhang and Awasthi, 2014);(Uysal and } \\
\text { Tosun, 2014) }\end{array}$ \\
\hline
\end{tabular}




\begin{tabular}{|l|l|l|}
\hline 17 & Green design & $\begin{array}{l}\text { (Sajjad, Eweje and Tappin, 2015); (Zhang and } \\
\text { Awasthi, 2014); (Uysal and Tosun, 2014); (Wolf, } \\
\text { 2014). }\end{array}$ \\
\hline 18 & Successful stock administration & $\begin{array}{l}\text { (Patil and Kant, 2014); (Kara et al., 2015);( } \\
\text { Sadaghiani et al., 2017). }\end{array}$ \\
\hline 19 & Natural instruction and preparing & $\begin{array}{l}\text { (Zhang and Awasthi, 2014);(Zhu, Sarkis and Lai, } \\
\text { 2012);(Liu, Low, and He ,2012). }\end{array}$ \\
\hline 20 & Authoritative performance & $\begin{array}{l}\text { (Muduli et al.,2013);(Lee et al.,2012);(Sarkis } \\
\text {,2012). }\end{array}$ \\
\hline 21 & Supplier commitment & (Manville et al., 2012); (Näslund, 2013). \\
\hline 22 & Choice of manageable practices & (Muduli et al., 2013);( Ofori, 2000). \\
\hline 23 & Representative strengthening & (Rao ,2002); (Walker et al., 2008) \\
\hline 24 & Provider inclusion in supportability & (Eltayeb et al, 2011);(Seuring ,2013). \\
\hline 25 & $\begin{array}{l}\text { Connecting SSCM to prizes and } \\
\text { acknowledgment }\end{array}$ & (Hervani et al.,2005);( Sarkis,2003) \\
\hline
\end{tabular}

\section{Enablers identified for modeling}

The vast majority of the case association's top administration faculty were associated with the choice board along with one mastery specialist of the SCM field. The specialists are very much experienced in their abstract fields and independently address mastery in various elements of SSCM. The specialist with rich experience (13 years) in receiving economical production network rehearses was incorporated as the specialists in the current investigation. There were seven specialists in the choice board, six from a similar association and one expert whose subtleties are given in Table 2.

The selected list of SSCMEs was then presented to the expert panel to finalize SSCMEs through brainstorming, and the shortlisted enablers were later used as input for ISM approach. Table 3 shows the enablers that were discovered through a literature review and expert consultation. The VAXO review was to be completed by an expert jury.The experts are given the details of factors and later asked to fill the Table 4 Experts need to review all the elements together carefully. These are the main inputs for ISM, and any variation in these input values leads to an inappropriate structural hierarchy of SSCMEs.

Table 2- Experts on the decision-making team

\begin{tabular}{|c|l|l|c|}
\hline Expert & \multicolumn{1}{|c|}{ Position } & \multicolumn{1}{|c|}{ Degree } & $\begin{array}{c}\text { Years of } \\
\text { practical } \\
\text { experience }\end{array}$ \\
\hline 1 & Director & Master of Business Administrations & 25 \\
\hline 2 & Production Manager & Bachelor in Textile Engineering & 18 \\
\hline 3 & Operations Manager & Bachelor in Textile Engineering & 15 \\
\hline 4 & $\begin{array}{l}\text { Manager of Safety and the } \\
\text { Environment }\end{array}$ & Bachelor in Environmental Management & 12 \\
\hline 5 & Production Engineer & Bachelor in Mechanical Engineering & 10 \\
\hline 6 & SSCM Consultant & Master of Business Administrations & 13 \\
\hline
\end{tabular}

\section{INTERPRETIVE STRUCTURAL MODELLING METHODOLOGY}

Interpretive Structural Modeling (ISM) is a technique for creating a progressive system of framework Enablers to speak to the framework structure. ISM (interpretive auxiliary displaying) is an intuitive learning mechanism in which a large number of different and directly linked components are arranged into a comprehensive, deliberate model. The fundamental thought of ISM is to break down a 
confounded framework into a few subsystems (parts) by utilizing the practical experience of specialists and their insight. The method is interpretive since the gathering's decision determines whether and how the Enablers are related. It's mostly focused on relationships, with a general framework being omitted from the bewildering array of Enablers. The method is interpretive since the gathering's decision determines whether and how the Enablers are related. It's mostly focused on relationships, with a general framework being omitted from the bewildering array of Enablers.

Gorane and Kant (2013) have connected the ISM strategy to demonstrate inventory network factors to distinguish key factors by utilizing immediate just as circuitous between connections among the elements. Hsiao et al. (2013) have used the ISM strategy to dissect a portion of the vital measure on item family improvement and have demonstrated the between connections of paradigm. Kannan et al. (2009) have utilized the ISM approach to build up a progressive system of activity required to choose the switch coordination's gave in a half breed frame by consolidating it with TOPSIS. Beikkhakhian et al. (2015) encompass use ISM philosophy towards model the readiness of the inventory network. Haleem et al. (2011) have utilized ISM to display the essential achievement variables of world-class production.

\section{Modelling of SSCM Enablers}

Step-1: Images (V, A, X, O) were used to investigate SSCMEs in the construction of the SSIM to represent the relationship between the empowering agents I and $\mathrm{j}$ ).

V-SSCME i will achieve SSCME j.

A-SSCME $\mathrm{j}$ will achieve SSCME i.

$\mathrm{X}-\mathrm{SSCME} \mathrm{i}$ and $\mathrm{j}$ will achieve one another.

O- SSCME $\mathrm{i}$ and $\mathrm{j}$ are random.

Table 3- Select SSCM enablers from expert review

\begin{tabular}{|l|l|l|l|}
\hline $\begin{array}{l}\text { SSCM } \\
\text { CODE }\end{array}$ & Enablers of SSCM & $\begin{array}{l}\text { SSCM } \\
\text { CODE }\end{array}$ & Enablers of SSCM \\
\hline SSCM1 & Maintainable Organizational Culture & SSCM11 & Information Sharing \\
\hline SSCM2 & Health and safety issues & SSCM12 & Powerful correspondence \\
\hline SSCM3 & Natural Product Design & SSCM13 & SSCM venture following and checking \\
\hline SSCM4 & Appropriation of wellbeing norms & SSCM14 & Green design \\
\hline SSCM5 & Green Purchasing & SSCM15 & Successful stock administration \\
\hline SSCM6 & Reception of green practices & SSCM16 & Strategic Planning \\
\hline SSCM7 & Linking SSCM to Customers & SSCM17 & Management Engagement \\
\hline SSCM8 & $\begin{array}{l}\text { Aligning government sustainability } \\
\text { approaches with the framework }\end{array}$ & SSCM18 & Supplier Commitment \\
\hline SSCM9 & Benchmarking System & SSCM19 & Choice of manageable practices \\
\hline SSCM10 & Customer satisfaction & SSCM20 & Representative strengthening \\
\hline
\end{tabular}

Table 4- Structural Self Interaction Matrix (SSIM) for SSCMEs

\begin{tabular}{|c|c|c|c|c|c|c|c|c|c|c|c|c|c|c|c|c|c|c|c|}
\hline $\begin{array}{l}\text { SSCM } \\
\text { Code }\end{array}$ & 20 & 19 & 18 & 17 & 16 & 15 & 14 & 13 & 12 & 11 & 10 & 9 & 8 & 7 & 6 & 5 & 4 & 3 & 2 \\
\hline SSCM 1 & $\mathrm{X}$ & $\mathrm{V}$ & $\mathrm{V}$ & $\mathrm{X}$ & $\mathrm{V}$ & $\mathrm{V}$ & $\mathrm{V}$ & $\mathrm{X}$ & $\mathrm{V}$ & $\mathrm{X}$ & $\mathrm{V}$ & $\mathrm{V}$ & $\mathrm{X}$ & $\mathrm{V}$ & $\mathrm{V}$ & $\mathrm{V}$ & $\mathrm{V}$ & $\mathrm{V}$ & $\mathrm{V}$ \\
\hline SSCM 2 & $\mathrm{~V}$ & $\mathrm{~V}$ & $\mathrm{~V}$ & $X$ & $\mathrm{~A}$ & $\mathrm{~A}$ & $\mathrm{~V}$ & $\mathrm{~A}$ & $\mathrm{O}$ & $\mathrm{A}$ & $\mathrm{V}$ & $\mathrm{A}$ & $\mathrm{A}$ & $\mathrm{O}$ & $\mathrm{A}$ & $\mathrm{A}$ & $\mathrm{A}$ & $\mathrm{A}$ & \\
\hline SSCM 3 & $X$ & V & $\mathrm{V}$ & $\mathrm{V}$ & $\mathrm{V}$ & A & $\mathrm{V}$ & $\mathrm{O}$ & $\mathrm{V}$ & $\mathrm{O}$ & $\mathrm{V}$ & A & A & A & A & $\mathrm{O}$ & A & & \\
\hline SSCM 4 & $\mathrm{~V}$ & $\mathrm{~V}$ & $\mathrm{X}$ & $\mathrm{X}$ & $\mathrm{V}$ & $\mathrm{O}$ & $\mathrm{V}$ & $\mathrm{O}$ & $\mathrm{V}$ & $\mathrm{V}$ & $\mathrm{X}$ & $\mathrm{V}$ & A & $\mathrm{A}$ & $\mathrm{V}$ & $\mathrm{V}$ & & & \\
\hline
\end{tabular}




\begin{tabular}{|c|c|c|c|c|c|c|c|c|c|c|c|c|c|c|c|}
\hline SSCM 5 & $\mathrm{~V}$ & $X$ & $\mathrm{~V}$ & $\mathrm{~V}$ & $\mathrm{~V}$ & $\mathrm{O}$ & $\mathrm{V}$ & $\mathrm{O}$ & $\mathrm{V}$ & $\mathrm{V}$ & $\mathrm{X}$ & $\mathrm{V}$ & $\mathrm{A}$ & $\mathrm{O}$ & $\mathrm{A}$ \\
\hline SSCM 6 & $\mathrm{~V}$ & $\mathrm{~V}$ & $\mathrm{X}$ & $\mathrm{V}$ & $\mathrm{V}$ & $\mathrm{O}$ & $\mathrm{V}$ & $\mathrm{O}$ & $X$ & $\mathrm{~V}$ & $\mathrm{~V}$ & $\mathrm{~V}$ & $\mathrm{~A}$ & $\mathrm{~A}$ & \\
\hline SSCM 7 & $X$ & $\mathrm{~V}$ & $X$ & $\mathrm{~V}$ & $\mathrm{~V}$ & $\mathrm{~V}$ & $\mathrm{~V}$ & $\mathrm{~V}$ & $\mathrm{~V}$ & $\mathrm{~V}$ & $\mathrm{~V}$ & $\mathrm{~V}$ & $\mathrm{~V}$ & & \\
\hline SSCM 8 & $\mathrm{~V}$ & $\mathrm{X}$ & $\mathrm{V}$ & $\mathrm{V}$ & $\mathrm{X}$ & $\mathrm{V}$ & $\mathrm{V}$ & $\mathrm{X}$ & $\mathrm{X}$ & $\mathrm{V}$ & $\mathrm{A}$ & $\mathrm{V}$ & & & \\
\hline SSCM 9 & $\mathrm{~V}$ & $\mathrm{~V}$ & $\mathrm{O}$ & $\mathrm{V}$ & $\mathrm{V}$ & A & $\mathrm{V}$ & $\mathrm{O}$ & $\mathrm{V}$ & $\mathrm{O}$ & $\mathrm{V}$ & & & & \\
\hline SSCM 10 & $\mathrm{~V}$ & $\mathrm{~V}$ & $\mathrm{~V}$ & A & $\mathrm{O}$ & A & $X$ & A & $\mathrm{A}$ & A & & & & & \\
\hline SSCM 11 & $\mathrm{~V}$ & $\mathrm{~V}$ & $X$ & $\mathrm{~V}$ & $\mathrm{O}$ & $\mathrm{O}$ & $\mathrm{V}$ & $\mathrm{O}$ & $\mathrm{V}$ & & & & & & \\
\hline SSCM 12 & $\mathrm{~V}$ & $X$ & $\mathrm{~V}$ & $\mathrm{~V}$ & $\mathrm{O}$ & $\mathrm{A}$ & $\mathrm{V}$ & $\mathrm{O}$ & & & & & & & \\
\hline SSCM 13 & $\mathrm{~V}$ & $\mathrm{~V}$ & $X$ & V & $\mathrm{V}$ & $\mathrm{O}$ & $\mathrm{V}$ & & & & & & & & \\
\hline SSCM 14 & $\mathrm{X}$ & $\mathrm{V}$ & $X$ & $\mathrm{O}$ & $\mathrm{A}$ & $\mathrm{A}$ & & & & & & & & & \\
\hline SSCM 15 & $\mathrm{~V}$ & $\mathrm{~V}$ & $X$ & V & $\mathrm{V}$ & & & & & & & & & & \\
\hline SSCM 16 & $\mathrm{X}$ & $\mathrm{X}$ & $\mathrm{V}$ & $\mathrm{V}$ & & & & & & & & & & & \\
\hline SSCM 17 & $\mathrm{~V}$ & $\mathrm{~V}$ & $X$ & & & & & & & & & & & & \\
\hline SSCM 18 & $\mathrm{X}$ & $X$ & & & & & & & & & & & & & \\
\hline SSCM 19 & $\mathrm{X}$ & & & & & & & & & & & & & & \\
\hline SSCM 20 & & & & & & & & & & & & & & & \\
\hline
\end{tabular}

Step-2: Transformation of SSIM into a twofold network speaks to the underlying reachability framework (IRM). Table 5 shows IRM, in which the SSIM images (V, A, X, O) are transformed into double structures ( 0 and 1$)$. The following are the dual transformation standards:

When the ( $\mathrm{i} j$ ) esteem in SSIM shows V,the ( $\mathrm{i} j$ ) esteem in IRM changes to 1 , while the ( $\mathrm{j}$, $\mathrm{i}$ )esteem changes to 0 .

When the SSIM esteem (i j) shows A, the ( $\mathrm{i}$ j) esteem in IRM becomes 0 and the $(\mathrm{j}, \mathrm{i})$ esteem becomes 1 .

When the SSIM esteem ( $i, j)$ shows $X$, the $(i, j)$ esteem in IRM becomes 1 , and $(j, i)$ esteem becomes 1 .

When the SSIM esteem (i, j) shows $O$, the $(i, j)$ esteem in IRM becomes 0 , and $(j, i)$ esteem becomes 0 .

Table 5- Initial Matrix for Reachability (IRM) for SSCMEs

\begin{tabular}{|l|c|c|c|c|c|c|c|c|c|c|c|c|c|c|c|c|c|c|c|c|}
\hline $\begin{array}{l}\text { SSCM } \\
\text { Code }\end{array}$ & $\mathbf{1}$ & $\mathbf{2}$ & $\mathbf{3}$ & $\mathbf{4}$ & $\mathbf{5}$ & $\mathbf{6}$ & $\mathbf{7}$ & $\mathbf{8}$ & $\mathbf{9}$ & $\mathbf{1 0}$ & $\mathbf{1 1}$ & $\mathbf{1 2}$ & $\mathbf{1 3}$ & $\mathbf{1 4}$ & $\mathbf{1 5}$ & $\mathbf{1 6}$ & $\mathbf{1 7}$ & $\mathbf{1 8}$ & $\mathbf{1 9}$ & $\mathbf{2 0}$ \\
\hline SSCM 1 & 1 & 1 & 1 & 0 & 0 & 0 & 0 & 0 & 0 & 1 & 0 & 1 & 0 & 1 & 0 & 1 & 1 & 1 & 1 & 1 \\
\hline SSCM 2 & 1 & 1 & 1 & 1 & 1 & 1 & 1 & 1 & 1 & 1 & 1 & 1 & 1 & 1 & 1 & 1 & 1 & 1 & 1 & 1 \\
\hline SSCM 3 & 0 & 1 & 1 & 0 & 1 & 0 & 0 & 0 & 1 & 1 & 1 & 1 & 0 & 1 & 0 & 1 & 1 & 1 & 1 & 1 \\
\hline SSCM 4 & 0 & 1 & 1 & 1 & 1 & 1 & 0 & 0 & 1 & 1 & 1 & 1 & 0 & 1 & 0 & 1 & 1 & 1 & 1 & 1 \\
\hline SSCM 5 & 0 & 1 & 1 & 1 & 1 & 1 & 0 & 0 & 1 & 1 & 1 & 1 & 0 & 1 & 0 & 1 & 1 & 1 & 1 & 1 \\
\hline SSCM 6 & 0 & 1 & 1 & 0 & 0 & 1 & 0 & 0 & 1 & 1 & 0 & 1 & 0 & 1 & 0 & 0 & 1 & 1 & 1 & 1 \\
\hline SSCM 7 & 1 & 1 & 1 & 1 & 1 & 1 & 1 & 1 & 1 & 1 & 1 & 1 & 1 & 1 & 1 & 1 & 1 & 1 & 1 & 1 \\
\hline SSCM 8 & 0 & 1 & 1 & 1 & 0 & 1 & 0 & 1 & 1 & 0 & 1 & 1 & 1 & 0 & 1 & 1 & 0 & 0 & 0 & 0 \\
\hline SSCM 9 & 0 & 1 & 1 & 0 & 0 & 0 & 0 & 0 & 1 & 1 & 0 & 1 & 0 & 1 & 0 & 1 & 1 & 1 & 1 & 1 \\
\hline SSCM 10 & 0 & 0 & 0 & 0 & 0 & 0 & 0 & 0 & 0 & 1 & 0 & 0 & 0 & 1 & 0 & 0 & 0 & 1 & 1 & 1 \\
\hline SSCM 11 & 0 & 1 & 0 & 0 & 0 & 0 & 0 & 0 & 0 & 1 & 1 & 1 & 0 & 1 & 0 & 0 & 1 & 1 & 1 & 1 \\
\hline SSCM 12 & 0 & 1 & 0 & 0 & 0 & 0 & 0 & 0 & 0 & 1 & 0 & 1 & 0 & 1 & 0 & 0 & 1 & 1 & 1 & 1 \\
\hline
\end{tabular}




\begin{tabular}{|l|l|l|l|l|l|l|l|l|l|l|l|l|l|l|l|l|l|l|l|l|}
\hline SSCM 13 & 0 & 1 & 0 & 0 & 0 & 0 & 0 & 0 & 0 & 1 & 0 & 0 & 1 & 1 & 0 & 1 & 1 & 1 & 1 & 1 \\
\hline SSCM 14 & 0 & 0 & 0 & 0 & 0 & 0 & 0 & 0 & 0 & 1 & 0 & 0 & 0 & 0 & 0 & 0 & 0 & 1 & 1 & 1 \\
\hline SSCM 15 & 0 & 1 & 0 & 0 & 0 & 0 & 0 & 0 & 1 & 0 & 0 & 0 & 0 & 0 & 0 & 0 & 1 & 1 & 1 & 1 \\
\hline SSCM 16 & 0 & 1 & 0 & 1 & 0 & 0 & 0 & 0 & 0 & 1 & 1 & 0 & 1 & 1 & 0 & 1 & 1 & 1 & 1 & 1 \\
\hline SSCM 17 & 0 & 1 & 0 & 0 & 0 & 0 & 0 & 0 & 0 & 1 & 0 & 0 & 0 & 1 & 0 & 0 & 1 & 1 & 1 & 1 \\
\hline SSCM 18 & 0 & 0 & 0 & 0 & 0 & 0 & 0 & 0 & 0 & 0 & 0 & 0 & 0 & 1 & 0 & 0 & 0 & 1 & 1 & 1 \\
\hline SSCM 19 & 0 & 0 & 0 & 0 & 0 & 0 & 0 & 0 & 0 & 0 & 1 & 0 & 0 & 0 & 0 & 0 & 0 & 0 & 1 & 1 \\
\hline SSCM 20 & 0 & 0 & 0 & 0 & 0 & 0 & 0 & 0 & 0 & 0 & 0 & 0 & 0 & 0 & 0 & 0 & 0 & 0 & 0 & 1 \\
\hline
\end{tabular}

Step-3: In the wake of setting up the underlying reachability lattice, the following stage incorporates evacuation of transitivity. The transitivity of relation is the fundamental formation in ISM. As per this presumption, if a driver $\mathrm{C} 1$ is identified with driver $\mathrm{C} 2$ and $\mathrm{C} 2$ is identified with $\mathrm{C} 3$, at that point, $\mathrm{C} 1$ is identified with $\mathrm{C} 3$. Consequently, after the expulsion of transitivity, the Final reachability framework is readied. Table 6 speaks to a conclusive reachability grid.

Table 6 - Final Reachability Matrix (FRM) for SSCMEs

\begin{tabular}{|c|c|c|c|c|c|c|c|c|c|c|c|c|c|c|c|c|c|c|c|c|}
\hline SSCM Code & 1 & 2 & 3 & 4 & 5 & 6 & 7 & 8 & 9 & 10 & 11 & 12 & 13 & 14 & 15 & 16 & 17 & 18 & 19 & 20 \\
\hline SSCM 1 & 1 & 1 & 1 & 0 & 0 & 0 & 0 & 0 & 0 & 1 & 0 & 1 & 0 & 1 & 0 & 1 & 1 & 1 & 1 & 1 \\
\hline SSCM 2 & 1 & 1 & 1 & 1 & 1 & 1 & 1 & 1 & 1 & 1 & 1 & 1 & 1 & 1 & 1 & 1 & 1 & 1 & 1 & 1 \\
\hline SSCM 3 & 0 & 1 & 1 & 0 & 1 & 0 & 0 & 0 & 1 & 1 & 1 & 1 & 0 & 1 & 0 & 1 & 1 & 1 & 1 & 1 \\
\hline SSCM 4 & 0 & 1 & 1 & 1 & 1 & 1 & 0 & 0 & 1 & 1 & 1 & 1 & 0 & 1 & 0 & 1 & 1 & 1 & 1 & 1 \\
\hline SSCM 5 & 0 & 1 & 1 & 1 & 1 & 1 & 0 & 0 & 1 & 1 & 1 & 1 & 0 & 1 & 0 & 1 & 1 & 1 & 1 & 1 \\
\hline SSCM 6 & 0 & 1 & 1 & 0 & 0 & 1 & 0 & 0 & 1 & 1 & 0 & 1 & 0 & 1 & 0 & 0 & 1 & 1 & 1 & 1 \\
\hline SSCM 7 & 1 & 1 & 1 & 1 & 1 & 1 & 1 & 1 & 1 & 1 & 1 & 1 & 1 & 1 & 1 & 1 & 1 & 1 & 1 & 1 \\
\hline SSCM 8 & 0 & 1 & 1 & 1 & 0 & 1 & 0 & 1 & 1 & 0 & 1 & 1 & 1 & 0 & 1 & 1 & 0 & 0 & 0 & 0 \\
\hline SSCM 9 & 0 & 1 & 1 & 0 & $1^{\#}$ & 0 & 0 & 0 & 1 & 1 & 0 & 1 & 0 & 1 & 0 & 1 & 1 & 1 & 1 & 1 \\
\hline SSCM 10 & 0 & 0 & 0 & 0 & 0 & 0 & 0 & 0 & 0 & 1 & 0 & 0 & 0 & 1 & 0 & 0 & 0 & 1 & 1 & 1 \\
\hline SSCM 11 & 0 & 1 & 0 & 0 & 0 & 0 & 0 & 0 & 0 & 1 & 1 & 1 & 0 & 1 & 0 & 0 & 1 & 1 & 1 & 1 \\
\hline SSCM 12 & 0 & 1 & $1^{\#}$ & 0 & 0 & 0 & 0 & 0 & 0 & 1 & $1^{\#}$ & 1 & 0 & 1 & 0 & 0 & 1 & 1 & 1 & 1 \\
\hline SSCM 13 & 0 & 1 & 0 & 0 & 0 & 0 & 0 & 0 & 0 & 1 & 0 & 0 & 1 & 1 & 0 & 1 & 1 & 1 & 1 & 1 \\
\hline SSCM 14 & 0 & 0 & 0 & 0 & 0 & 0 & 0 & 0 & 0 & 1 & 0 & 0 & 0 & $1^{\#}$ & 0 & 0 & 0 & 1 & 1 & 1 \\
\hline SSCM 15 & 0 & 1 & 0 & 0 & 0 & 0 & 0 & 0 & 1 & 0 & 0 & 0 & 0 & 0 & 0 & 0 & 1 & 1 & 1 & 1 \\
\hline SSCM 16 & 0 & 1 & $1^{\#}$ & 1 & 0 & 0 & 0 & 0 & 0 & 1 & 1 & 0 & 1 & 1 & 0 & 1 & 1 & 1 & 1 & 1 \\
\hline SSCM 17 & 0 & 1 & 0 & 0 & 0 & 0 & 0 & 0 & 0 & 1 & 0 & 0 & 0 & 1 & 0 & 0 & 1 & 1 & 1 & 1 \\
\hline SSCM 18 & 0 & 0 & 0 & 0 & 0 & 0 & 0 & 0 & 0 & $1^{\#}$ & 0 & 0 & 0 & 1 & 0 & 0 & 0 & 1 & 1 & 1 \\
\hline SSCM 19 & 0 & 0 & 0 & 0 & 0 & 0 & 0 & 0 & 0 & 0 & 1 & 0 & 0 & 0 & 0 & 0 & 0 & 0 & 1 & 1 \\
\hline SSCM 20 & 0 & 0 & 0 & 0 & 0 & 0 & 0 & 0 & 0 & 0 & 0 & 0 & 0 & 0 & 0 & 0 & 0 & 0 & 0 & 1 \\
\hline
\end{tabular}

\section{\# represents transitivity}

Step-4: In the wake of expelling the transitivity, the subsequent stage incorporates level apportioning. The reachability band and precursor band for each SSCME are defined using FRM's guidance. The reachability band includes SSCME itself, as well as what others can achieve, while the predecessor band refers to SSCME and various SSCMEs that aid in its attainment. After setting up these two 
groups, the following stage incorporates the finding of their crossing point focuses. As shown in table 7 , the degrees of segment are made for sequential cycles, and different gatherings accomplish different things.

Table 7- The reachability matrix was partitioned in the final iteration.

\begin{tabular}{|c|c|c|c|c|}
\hline $\begin{array}{l}\text { SSCM } \\
\text { Code }\end{array}$ & Reachability Set & Antecedent Set & Intersection Set & $\begin{array}{l}\text { Level } \\
\text { Partition }\end{array}$ \\
\hline SSCM 1 & $1,2,3,10,12,14,16,17,18,19,20$ & $1,3,5,6,7,8,9$ & 3,1 & Level 4 \\
\hline SSCM 2 & $\begin{array}{l}1,2,3,4,5,6,7,8,9,10,11,12,13,14,15,16,17 \\
18,19,20\end{array}$ & 2,7 & 2,7 & Level 1 \\
\hline SSCM 3 & $2,3,5,9,10,11,12,14,16,17,18,19,20$ & $1,3,4,6,7,8$ & 3 & Level 4 \\
\hline SSCM 4 & $2,3,4,5,6,9,10,11,12,14,16,17,18,19,20$ & $1,4,5,7,8$ & 5,4 & Level 3 \\
\hline SSCM 5 & $2,3,4,5,6,9,10,11,12,14,16,17,18,19,20$ & $1,4,5,7,8$ & 5,4 & Level 3 \\
\hline SSCM 6 & $2,3,6,10,12,14,17,18,19,20$ & $1,4,5,6,7,8,9,12,15,16,17$ & $6,12,17$ & Level 5 \\
\hline SSCM 7 & $\begin{array}{l}1,2,3,4,5,6,7,8,9,10,11,12,13,14,15,16,17 \\
18,19,20\end{array}$ & 2,7 & 2,7 & Level 1 \\
\hline SSCM 8 & $\begin{array}{l}2,3,4,5,6,8,9,10,11,12,13,14,15,16,17,18,1 \\
9,20\end{array}$ & $1,7,8$ & 8 & Level 2 \\
\hline SSCM 9 & $2,9,10,14,15,17,18,19,20$ & $\begin{array}{l}1,3,4,5,6,7,8,9,10,11,12, \\
13,15,16\end{array}$ & 9,15 & Level 6 \\
\hline SSCM 10 & $2,10,12,14,17,18,19,20$ & $1,4,5,6,7,8,10,12$ & 10,12 & Level 5 \\
\hline SSCM 11 & $11,19,20$ & $\begin{array}{l}1,2,3,4,5,6,7,8,9,10,11,12 \\
13,14,15,16,17,18,19\end{array}$ & 11,19 & Level 8 \\
\hline SSCM 12 & $2,10,13,12,14,17,18,19,20$ & $1,7,8,12$ & 12 & Level 3 \\
\hline SSCM 13 & $2,10,13,14,16,17,18,19,20$ & $1,3,4,5,6,7,8,9,12,13,15,17$ & 13,17 & Level 5 \\
\hline SSCM 14 & $10,14,18,19,20$ & $\begin{array}{l}1,2,3,4,5,6,7,8,9,11,12 \\
13,14,15,16,17,18\end{array}$ & 18,14 & Level 7 \\
\hline SSCM 15 & $2,9,17,18,19,20$ & $\begin{array}{l}1,3,4,5,6,7,8,9,10,11,12 \\
13,14,15,16,17\end{array}$ & 9,15 & Level 6 \\
\hline SSCM 16 & $2,3,9,10,12,14,15,16,17,18,19,20$ & $1,7,8,16$ & 16 & Level 3 \\
\hline SSCM 17 & $2,6,10,12,14,17,18,19,20$ & $3,4,5,6,7,8,9,11,12,15,17$ & $6,17,12$ & Level 5 \\
\hline SSCM 18 & $10,14,18,19,20$ & $\begin{array}{l}1,2,3,4,5,6,7,8,9,11,12, \\
13,14,15,16,17,18\end{array}$ & 14,18 & Level 7 \\
\hline SSCM 19 & $11,19,20$ & $\begin{array}{l}1,2,3,4,5,6,7,8,9,10,11,12 \\
13,14,15,16,17,18,19\end{array}$ & 11,19 & Level 8 \\
\hline SSCM 20 & 20 & $\begin{array}{l}1,2,3,4,5,6,7,8,9,10,11,12 \\
13,14,15,16,17,18,19,20\end{array}$ & 20 & Level 9 \\
\hline
\end{tabular}

Step-5: The last advance of ISM incorporates the organizing of the SSCMEs at various dimensions through the dimension segment of the reachability grid. Figure 1 demonstrates the basic progression of SSCMEs, which speaks to the Enablers' relationship in the organized structure.

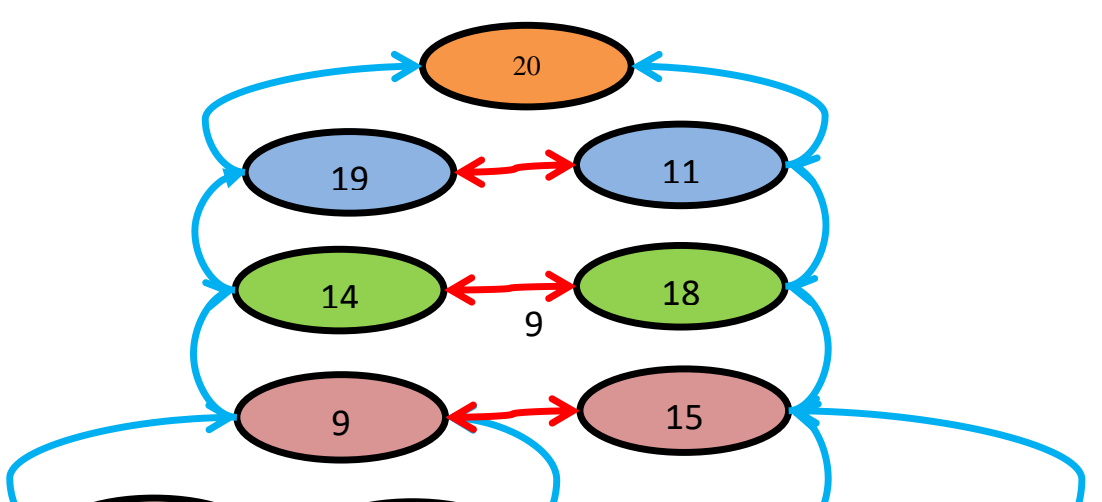


Fig. 1: Diagraph for SSCM

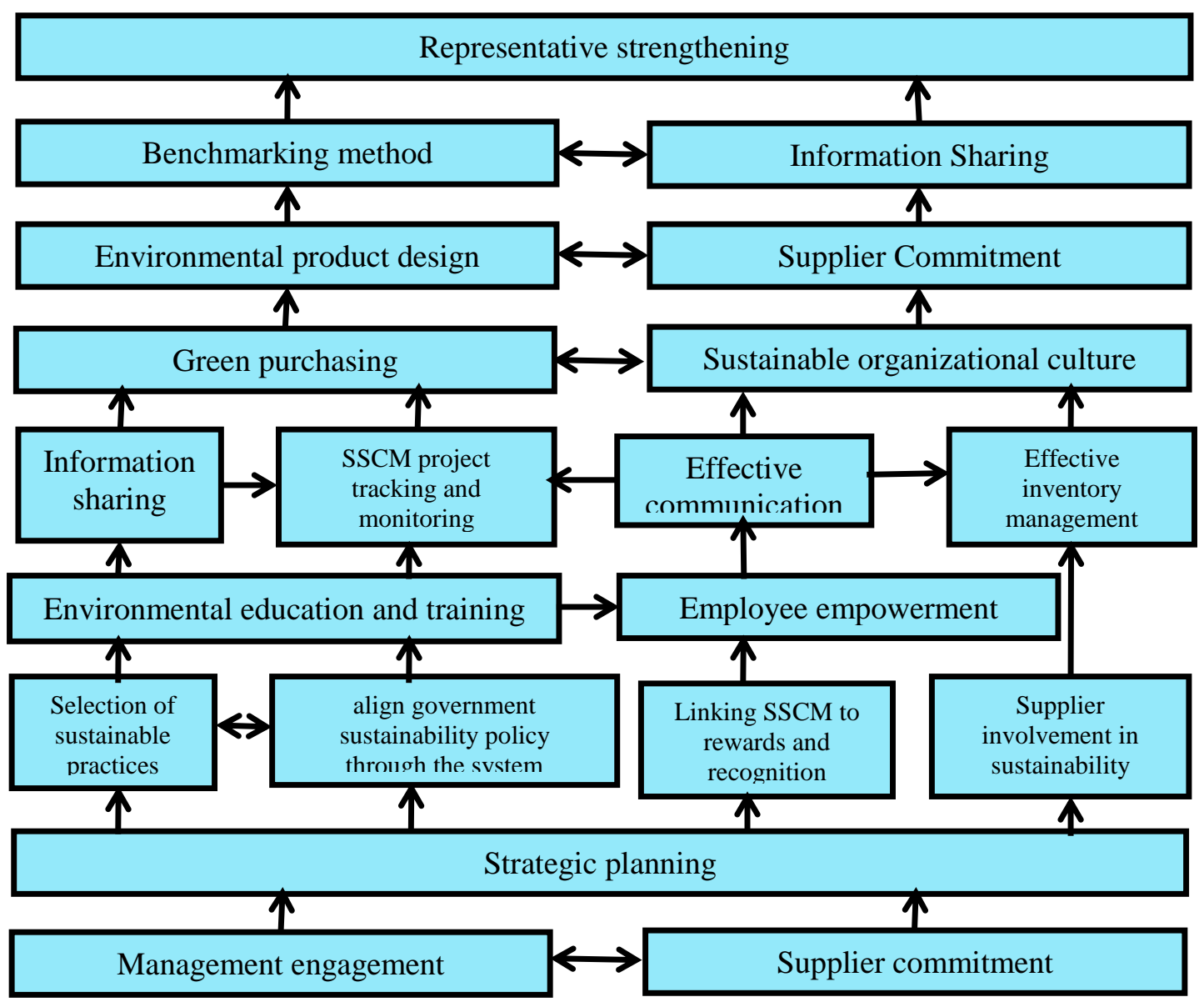

Fig. 2: Structural hierarchy model for SSCMEs

\section{MICMAC ANALYSIS OF SSCM ENABLERS}

Simply characterizing the dimensions of the parcel does not enable the professionals to settle on the right choices for the execution of SSCM, as it is vital to comprehend the intensity of driving just as a reliance on enablers incorporated into the model. The Fuzzy MICMAC analysis is combined in the final step of 
the investigation to overcome the depicted problem. The aim of including fluffy is to account for the uncertainty factor.

\section{MICMAC review of fuzziness}

During the development of the ISM-based model, any relationship among the SSCMEs was designated by 0 and 1 . As a consequence, if a relationship exists between two SSCMEs, it is replaced by 1 ; if it does not, it is replaced by 0 ; if it does, it is replaced by 1 ; and if it does not, it is replaced by 0 , while it is replaced by 1 in the case of equal value. However, in some situations, the relationship between two SSCMEs cannot be the same.

Some enablers may have a strong bond, while others may have a shaky one; regardless, the binary input will be 1. As a result, in MICMAC research, a fuzzy type of ISM is used to overcome this shortcoming of the ISM-based model. The fuzzy MICMAC analysis method is described in detail below.

\section{Matrix of binary direct reachability}

The interactions between SSCMEs are canvassed via Table 6 to obtain the binary direct reachability matrix, as defined in the ISM methodology (BDRM). All of Table 6's diagonal entries are replaced with zero to achieve BDRM. Since it is derived, the BDRM is depicted in Table 8.

Table 8 - Binary Direct Reachability Matrix (BDRM)

\begin{tabular}{|l|l|l|l|l|l|l|l|l|l|l|l|l|l|l|l|l|l|l|l|l|}
\hline $\begin{array}{l}\text { SSCM } \\
\text { Code }\end{array}$ & $\mathbf{1}$ & $\mathbf{2}$ & $\mathbf{3}$ & $\mathbf{4}$ & $\mathbf{5}$ & $\mathbf{6}$ & $\mathbf{7}$ & $\mathbf{8}$ & $\mathbf{9}$ & $\mathbf{1 0}$ & $\mathbf{1 1}$ & $\mathbf{1 2}$ & $\mathbf{1 3}$ & $\mathbf{1 4}$ & $\mathbf{1 5}$ & $\mathbf{1 6}$ & $\mathbf{1 7}$ & $\mathbf{1 8}$ & $\mathbf{1 9}$ & $\mathbf{2 0}$ \\
\hline SSCM 1 & 1 & 1 & 0 & 0 & 1 & 1 & 0 & 1 & 0 & 1 & 1 & 0 & 1 & 1 & 0 & 1 & 1 & 1 & 0 & 1 \\
\hline SSCM 2 & 1 & 0 & 0 & 1 & 1 & 1 & 0 & 1 & 0 & 1 & 0 & 1 & 1 & 1 & 0 & 0 & 0 & 1 & 1 & 0 \\
\hline SSCM 3 & 1 & 0 & 1 & 1 & 0 & 1 & 0 & 0 & 0 & 1 & 1 & 0 & 0 & 0 & 0 & 0 & 0 & 1 & 1 & 0 \\
\hline SSCM 4 & 1 & 0 & 1 & 0 & 1 & 0 & 1 & 0 & 1 & 0 & 1 & 0 & 0 & 1 & 1 & 0 & 1 & 0 & 0 & 0 \\
\hline SSCM 5 & 0 & 1 & 1 & 1 & 0 & 1 & 0 & 1 & 0 & 0 & 1 & 0 & 0 & 1 & 1 & 0 & 0 & 1 & 1 & 0 \\
\hline SSCM 6 & 1 & 0 & 1 & 1 & 1 & 0 & 0 & 1 & 0 & 1 & 0 & 0 & 1 & 0 & 0 & 0 & 1 & 0 & 1 & 1 \\
\hline SSCM 7 & 0 & 1 & 0 & 1 & 0 & 1 & 1 & 1 & 0 & 1 & 0 & 1 & 1 & 1 & 0 & 1 & 1 & 0 & 1 & 1 \\
\hline SSCM 8 & 0 & 1 & 0 & 1 & 1 & 0 & 1 & 0 & 1 & 0 & 1 & 1 & 1 & 1 & 1 & 0 & 1 & 1 & 1 & 0 \\
\hline SSCM 9 & 0 & 1 & 1 & 1 & 1 & 0 & 0 & 1 & 0 & 1 & 1 & 1 & 0 & 1 & 0 & 0 & 1 & 0 & 1 & 1 \\
\hline SSCM 10 & 1 & 0 & 1 & 0 & 0 & 0 & 1 & 0 & 0 & 1 & 0 & 0 & 1 & 1 & 0 & 1 & 0 & 1 & 1 & 0 \\
\hline SSCM 11 & 1 & 1 & 0 & 1 & 0 & 1 & 0 & 1 & 1 & 0 & 0 & 1 & 0 & 0 & 0 & 0 & 0 & 1 & 0 & 1 \\
\hline SSCM 12 & 0 & 1 & 1 & 1 & 0 & 0 & 1 & 0 & 1 & 1 & 0 & 0 & 1 & 1 & 0 & 1 & 1 & 0 & 1 & 0 \\
\hline SSCM 13 & 0 & 1 & 0 & 1 & 0 & 0 & 0 & 1 & 0 & 1 & 0 & 1 & 1 & 1 & 1 & 1 & 0 & 1 & 0 & 1 \\
\hline SSCM 14 & 1 & 0 & 0 & 1 & 0 & 1 & 1 & 0 & 0 & 0 & 1 & 1 & 0 & 0 & 1 & 0 & 0 & 0 & 1 & 0 \\
\hline SSCM 15 & 0 & 1 & 1 & 1 & 0 & 1 & 0 & 1 & 1 & 0 & 0 & 1 & 0 & 1 & 1 & 1 & 0 & 1 & 1 & 0 \\
\hline SSCM 16 & 0 & 1 & 1 & 0 & 0 & 1 & 0 & 1 & 0 & 1 & 1 & 0 & 1 & 0 & 0 & 1 & 1 & 0 & 1 & 0 \\
\hline SSCM 17 & 0 & 1 & 1 & 0 & 1 & 1 & 1 & 0 & 1 & 1 & 0 & 0 & 1 & 1 & 0 & 1 & 0 & 1 & 0 & 1 \\
\hline SSCM 18 & 1 & 0 & 0 & 1 & 0 & 1 & 1 & 0 & 0 & 1 & 0 & 0 & 1 & 0 & 1 & 0 & 0 & 1 & 1 & 1 \\
\hline SSCM 19 & 0 & 1 & 1 & 0 & 1 & 0 & 0 & 1 & 0 & 1 & 1 & 0 & 1 & 0 & 1 & 0 & 0 & 1 & 0 & 1 \\
\hline SSCM 20 & 1 & 0 & 1 & 0 & 1 & 0 & 1 & 0 & 0 & 0 & 1 & 0 & 0 & 0 & 1 & 0 & 1 & 0 & 1 & 0 \\
\hline
\end{tabular}




\section{Direct reachability matrix with fuzziness (FDRM)}

Experts' ability to provide a comprehensive and accurate relationship between enablers is limited by the Standard Matrix Impact of Cross Multiplication Applied to Classification (MICMAC) analysis, which only considers the binary relationship between enablers in terms of 0 and 1 , restricting their ability to provide a detailed and accurate relationship between enablers. Traditional MICMAC analysis is combined with fuzzy set theory to better describe the interactions among the enablers. As seen in Table 9, instead of 0 and 1, values between these two digits are used as a scale in the standard analysis. (Sindhu and colleagues, 2016). The decision panel was asked to provide feedback on the new scale in order to achieve the FDRM, and their suggestions were incorporated into the BDRM. Table 10 shows the final FDRM obtained by using a fuzzy scale to incorporate all expert opinions.

Table 9 Depth of relation value

\begin{tabular}{|c|c|c|c|c|c|c|c|}
\hline $\begin{array}{c}\text { Depth of } \\
\text { relation }\end{array}$ & No & $\begin{array}{c}\text { Very Low } \\
(\mathrm{VL})\end{array}$ & $\begin{array}{c}\text { Low } \\
(\mathrm{LW})\end{array}$ & $\begin{array}{c}\text { Medium } \\
(\mathrm{MD})\end{array}$ & High (HG) & Very High (VH) & Complete \\
\hline Value & 0 & 0.1 & 0.3 & 0.5 & 0.7 & 0.9 & 1 \\
\hline
\end{tabular}

Table 10- Fuzzy Direct Reachability Matrix (FDRM)

\begin{tabular}{|c|c|c|c|c|c|c|c|c|c|c|c|c|c|c|c|c|c|c|c|c|}
\hline $\begin{array}{l}\text { SSCM } \\
\text { Code }\end{array}$ & 1 & 2 & 3 & 4 & 5 & 6 & 7 & 8 & 9 & 10 & 11 & 12 & 13 & 14 & 15 & 16 & 17 & 18 & 19 & 20 \\
\hline SSCM 1 & 0 & 0.7 & 0.7 & 0.5 & 0.5 & 0.5 & 0.7 & 0.7 & 0.7 & 0.9 & 0.7 & 0.7 & 0.7 & 0.7 & 0.7 & 0.9 & 0.5 & 0.3 & 0.3 & 0.5 \\
\hline SSCM 2 & 0 & 0 & 0.5 & 0 & 0 & 0 & 0 & 0 & 0 & 0.3 & 0 & 0 & 0 & 0.7 & 0 & 0 & 0.9 & 0.7 & 0.5 & 0.5 \\
\hline SSCM 3 & 0 & 0.5 & 0 & 0 & 0 & 0 & 0.3 & 0 & 0 & 0.9 & 0 & 0.9 & 0 & 0.7 & 0 & 0.9 & 0.9 & 0.5 & 0.5 & 0.5 \\
\hline SSCM 4 & 0 & 0.5 & 0.7 & 0 & 0.9 & 0.7 & 0 & 0 & 0.9 & 0.5 & 0.7 & 0.7 & 0 & 0.5 & 0 & 0.7 & 0.5 & 0.5 & 0.5 & 0.3 \\
\hline SSCM 5 & 0 & 0.7 & 0.9 & 0 & 0 & 0 & 0 & 0 & 0.9 & 0.5 & 0.9 & 0.9 & 0 & 0.5 & 0 & 0.9 & 0.7 & 0.5 & 0.5 & 0.5 \\
\hline SSCM 6 & 0 & 0.5 & 0.7 & 0.7 & 0.9 & 0 & 0 & 0 & 0.9 & 0.5 & 0.7 & 0.7 & 0 & 0.5 & 0 & 0.7 & 0.5 & 0.5 & 0.5 & 0.3 \\
\hline SSCM 7 & 0 & 0.5 & 0.5 & 0.9 & 0.7 & 0.9 & 0 & 0 & 0.7 & 0.5 & 0.5 & 0.5 & 0.9 & 0.5 & 0.9 & 0.5 & 0.5 & 0.5 & 0.3 & 0.3 \\
\hline SSCM 8 & 0.9 & 0.7 & 0.3 & 0.7 & 0.9 & 0.7 & 0.7 & 0.3 & 0.7 & 0.3 & 0.5 & 0.5 & 0.7 & 0.3 & 0.7 & 0.5 & 0.5 & 0.3 & 0.3 & 0.3 \\
\hline SSCM 9 & 0 & 0.7 & 0.9 & 0 & 0.9 & 0 & 0 & 0 & 0 & 0.5 & 0 & 0.7 & 0 & 0.5 & 0 & 0.9 & 0.7 & 0.5 & 0.5 & 0.5 \\
\hline SSCM 10 & 0 & 0 & 0 & 0 & 0 & 0 & 0 & 0 & 0 & 0 & 0 & 0 & 0 & 0.9 & 0 & 0 & 0 & 0.9 & 0.9 & 0.5 \\
\hline SSCM 11 & 0 & 0.7 & 0 & 0 & 0 & 0 & 0 & 0 & 0 & 0.7 & 0 & 0.5 & 0 & 0.7 & 0 & 0.5 & 0.9 & 0.5 & 0.5 & 0.5 \\
\hline SSCM 12 & 0 & 0.9 & 0.7 & 0 & 0 & 0 & 0 & 0 & 0 & 0.9 & 0.7 & 0 & 0 & 0.7 & 0 & 0 & 0.9 & 0.5 & 0.5 & 0.5 \\
\hline SSCM 13 & 0 & 0.5 & 0 & 0 & 0 & 0 & 0 & 0 & 0 & 0.5 & 0 & 0 & 0 & 0.5 & 0 & 0.9 & 0.5 & 0.5 & 0.5 & 0.3 \\
\hline SSCM 14 & 0 & 0 & 0 & 0 & 0 & 0 & 0 & 0 & 0 & 0.9 & 0 & 0 & 0 & 0 & 0 & 0 & 0 & 0.9 & 0.9 & 0.5 \\
\hline SSCM 15 & 0 & 0.5 & 0.9 & 0 & 0 & 0 & 0 & 0 & 0.9 & 0.5 & 0 & 0.5 & 0 & 0.5 & 0 & 0.3 & 0.5 & 0.3 & 0.3 & 0.3 \\
\hline SSCM 16 & 0 & 0.9 & 0.7 & 0 & 0 & 0 & 0 & 0 & 0 & 0.7 & 0 & 0 & 0 & 0.7 & 0 & 0 & 0.9 & 0.5 & 0.5 & 0.5 \\
\hline SSCM 17 & 0 & 0.9 & 0 & 0 & 0 & 0 & 0 & 0 & 0 & 0.9 & 0 & 0 & 0 & 0.9 & 0 & 0 & 0 & 0.5 & 0.5 & 0.5 \\
\hline SSCM 18 & 0 & 0 & 0 & 0 & 0 & 0 & 0 & 0 & 0 & 0 & 0 & 0 & 0 & 0 & 0 & 0 & 0 & 0 & 0.7 & 0.9 \\
\hline SSCM 19 & 0 & 0 & 0 & 0 & 0 & 0 & 0 & 0 & 0 & 0 & 0 & 0 & 0 & 0 & 0 & 0 & 0 & 0.7 & 0 & 0.9 \\
\hline SSCM 20 & 0 & 0 & 0 & 0 & 0 & 0 & 0 & 0 & 0 & 0 & 0 & 0 & 0 & 0 & 0 & 0 & 0 & 0 & 0 & 0 \\
\hline
\end{tabular}


The fuzzy MICMAC process begins with the FDRM obtained in the previous stage. Before the hierarchies of driving and dependency power are stabilised, the matrices are multiplied in this order.The fundamental theory of fuzzy multiplication is used to multiply the two matrices (Gorane and Kant, 2015). A Boolean matrix multiplication simplification is the foundation of fuzzy matrix multiplication. According to fuzzy set theory, when two fuzzy matrices are multiplied, the result is always a fuzzy matrix. The formula for multiplying two matrices is as follows.

$$
\mathrm{Z}=\mathrm{X} . \mathrm{Y}=\max \mathrm{n}\left[\min \left(\mathrm{x}_{\mathrm{in}}, \mathrm{y}_{\mathrm{nj}}\right)\right]
$$

Here $\mathrm{X}=\mathrm{x}_{\mathrm{in}}$ and $\mathrm{Y}=\mathrm{y}_{\mathrm{nj}}$

The FDRM obtained in the previous stage is used to start the fuzzy MICMAC operation. The matrices are multiplied in this order until the hierarchies of driving and dependency power are stabilised. The fundamental theory of fuzzy multiplication is used to multiply the two matrices (Gorane and Kant, 2015). A simplified Boolean matrix multiplication is the real fuzzy matrix multiplication. According to fuzzy set theory, when two fuzzy matrices are multiplied, the result is always a fuzzy matrix. The formula for multiplying two matrices is as follows.

Table 11- Fuzzy MICMAC stabilized Matrix

\begin{tabular}{|c|c|c|c|c|c|c|c|c|c|c|c|c|c|c|c|c|c|c|c|c|}
\hline Code & 1 & 2 & 3 & 4 & 5 & 6 & 7 & 8 & 9 & 10 & 11 & 12 & 13 & 14 & 15 & 16 & 17 & 18 & 19 & 20 \\
\hline 1 & 0.9 & 0.9 & 0.9 & 0.9 & 0.9 & 0.9 & 0.9 & 0 & 0.9 & 0.9 & 0.9 & 0.9 & 0.9 & 0.9 & 0.9 & 0.9 & 0.9 & 0.9 & 0.9 & 0.9 \\
\hline 2 & 0 & 0.9 & 0 & 0 & 0 & 0 & 0 & 0 & 0 & 0.9 & 0 & 0 & 0 & 0.9 & 0 & 0 & 0 & 0.9 & 0.9 & 0.9 \\
\hline 3 & 0 & 0.9 & 0.7 & 0 & 0 & 0 & 0 & 0 & 0 & 0.9 & 0.7 & 0 & 0 & 0.9 & 0 & 0 & 0.9 & 0.9 & 0.9 & 0.9 \\
\hline 4 & 0 & 0.9 & 0.9 & 0.7 & 0.9 & 0 & 0 & 0 & 0.9 & 0.9 & 0.9 & 0.9 & 0 & 0.9 & 0 & 0.9 & 0.9 & 0.9 & 0.9 & 0.9 \\
\hline 5 & 0 & 0.9 & 0.9 & 0 & 0.9 & 0 & 0 & 0 & 0 & 0.9 & 0.7 & 0.9 & 0 & 0.9 & 0 & 0.9 & 0.9 & 0.9 & 0.9 & 0.9 \\
\hline 6 & 0 & 0.9 & 0.9 & 0 & 0.9 & 0.7 & 0 & 0 & 0.9 & 0.9 & 0.9 & 0.9 & 0 & 0.9 & 0 & 0.9 & 0.9 & 0.9 & 0.9 & 0.9 \\
\hline 7 & 0 & 0.9 & 0.9 & 0.7 & 0.9 & 0.7 & 0 & 0 & 0.9 & 0.9 & 0.9 & 0.9 & 0 & 0.9 & 0 & 0.9 & 0.9 & 0.9 & 0.9 & 0.9 \\
\hline 8 & 0 & 0.9 & 0.9 & 0.9 & 0.9 & 0.9 & 0.9 & 0.9 & 0.9 & 0.9 & 0.9 & 0.9 & 0.9 & 0.9 & 0.9 & 0.9 & 0.9 & 0.9 & 0.9 & 0.9 \\
\hline 9 & 0 & 0.9 & 0.9 & 0 & 0 & 0 & 0 & 0 & 0.9 & 0.9 & 0.9 & 0.9 & 0 & 0.9 & 0 & 0.9 & 0.9 & 0.9 & 0.9 & 0.9 \\
\hline 10 & 0 & 0 & 0 & 0 & 0 & 0 & 0 & 0 & 0 & 0.9 & 0 & 0 & 0 & 0 & 0 & 0 & 0 & 0.9 & 0.9 & 0.9 \\
\hline 11 & 0 & 0.9 & 0.7 & 0 & 0 & 0 & 0 & 0 & 0 & 0.9 & 0.7 & 0 & 0 & 0.9 & 0 & 0 & 0.9 & 0.9 & 0.9 & 0.9 \\
\hline 12 & 0 & 0.9 & 0 & 0 & 0 & 0 & 0 & 0 & 0 & 0.9 & 0 & 0.9 & 0 & 0.9 & 0 & 0.9 & 0.9 & 0.9 & 0.9 & 0.9 \\
\hline 13 & 0 & 0.9 & 0.7 & 0 & 0 & 0 & 0 & 0 & 0 & 0.9 & 0 & 0 & 0 & 0.9 & 0 & 0 & 0.9 & 0.9 & 0.9 & 0.9 \\
\hline 14 & 0 & 0 & 0 & 0 & 0 & 0 & 0 & 0 & 0 & 0 & 0 & 0 & 0 & 0.9 & 0 & 0 & 0 & 0.9 & 0.9 & 0.9 \\
\hline 15 & 0 & 0.9 & 0.9 & 0 & 0.9 & 0 & 0 & 0 & 0 & 0.9 & 0.7 & 0.9 & 0 & 0.9 & 0 & 0.9 & 0.9 & 0.9 & 0.9 & 0.9 \\
\hline 16 & 0 & 0.9 & 0 & 0 & 0 & 0 & 0 & 0 & 0 & 0.9 & 0 & 0.9 & 0 & 0.9 & 0 & 0.9 & 0.9 & 0.9 & 0.9 & 0.9 \\
\hline 17 & 0 & 0 & 0 & 0 & 0 & 0 & 0 & 0 & 0 & 0.9 & 0 & 0 & 0 & 0.9 & 0 & 0 & 0.9 & 0.9 & 0.9 & 0.9 \\
\hline 18 & 0 & 0 & 0 & 0 & 0 & 0 & 0 & 0 & 0 & 0 & 0 & 0 & 0 & 0 & 0 & 0 & 0 & 0.7 & 0 & 0.9 \\
\hline 19 & 0 & 0 & 0 & 0 & 0 & 0 & 0 & 0 & 0 & 0 & 0 & 0 & 0 & 0 & 0 & 0 & 0 & 0 & 0.7 & 0.9 \\
\hline 20 & 0 & 0 & 0 & 0 & 0 & 0 & 0 & 0 & 0 & 0 & 0 & 0 & 0 & 0 & 0 & 0 & 0 & 0 & 0 & 0 \\
\hline
\end{tabular}



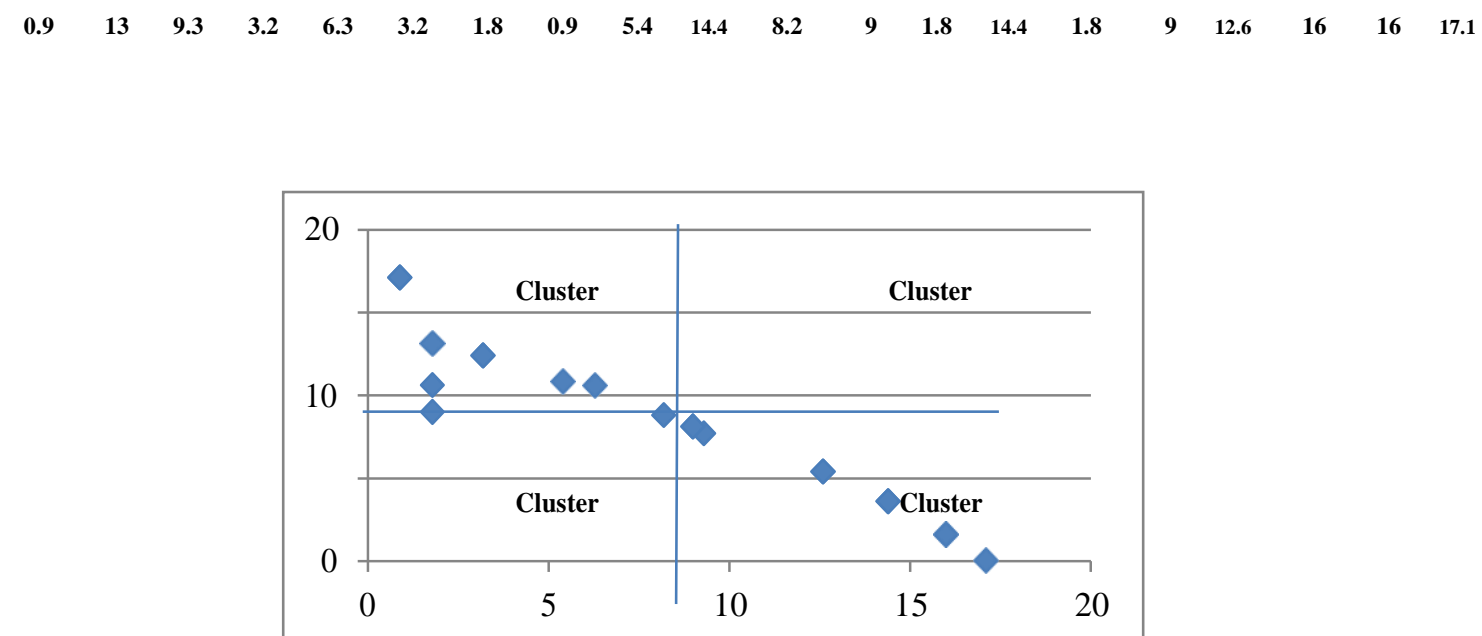

Fig.3: Cluster Diagram for SSCMEs

\section{Clusters' definition}

\section{Cluster I: Autonomous Enablers}

Self-governing or barred empowering agents are the enablers in this category. These empowering forces are located in the diagram's bottom left zone and represent powerless driving and fragile reliance. They show the properties off the mark inside the whole framework. None of the chose empowering agents falls under this bunch; thus it demonstrates that the shortlisted empowering agents are exact and most appropriate for the Indian material enterprises.

\section{Cluster II: Dependent Enablers}

This group includes enablers who are either needy or resultant. These empowering agents are located in the diagram's base right zone and exhibit weak driving and strong reliance force.They show the properties of yield factors inside the whole framework. Seven empowering influences fall under this bunch, which demonstrates that the shortlisted empowering influences are exceptionally subject to the info factors. Benchmarking frameworks, consumer loyalty, and upgraded hierarchical execution come out to be the most trustworthy empowering influences.

\section{Cluster III: Linkage Enablers}

The enablers in this cluster exhibit both a high level of influence and a high level of dependence. These enablers, which are located in the diagram's upper right zone, represent safe driving and a strong reliance force. They are viewed as the most delicate and shaky empowering agents. Any adjustment in these empowering agents impacts other empowering influences quickly, while the input impact on themselves additionally modifies their yield to the framework. There are no drivers in this zone, indicating that the ISM-acquired progressive construction is fully stable.

\section{Cluster IV: Driving Enablers}

The enablers in this group are powerful drivers who rely on other inspiring agents for support. These inspiring forces are located in the upper left zone of the map and have a strong driving and frail dependency force. In the execution stage, they act as initiators. These motivating factors assist in the achievement of other empowering influences and continue to contribute to the execution relationship.

\section{FINDINGS FROM THE ANALYSIS}

Because of the crossover organizing of cycles in the assembling association, it gets fundamental for experts to perceive and structure basic empowering agents efficiently. Since the reception of SSCM is viewed as a perplexing cycle, it is basic to distinguish the most critical empowering influences for fruitful SSCM appropriation. After evaluating numerous research papers and expert views, the current report helps classify and structure the most important enablers of SSCM. After the short posting cycle 
of empowering agents, twenty empowering agents were recognized, which were given as contribution to the ISM way to deal with building the progressive construction of SSCMEs. The result of the ISM model was taken as contribution to the fluffy MICMAC approach.

Using ISM and the Fuzzy MICMAC method, a progressive model of SSCMEs is developed in this report.The created model may assist chiefs with using this model to recognize and order the basic factors as indicated by the requirements of explicit Indian material businesses and explore the immediate and roundabout impacts of every factor on one another. The empowering agents recognized in this model are really nonexclusive for Indian material worries; for certain changes, it tends to be made more explicit to the vehicle, designing, measure enterprises, and so forth

The results of this study will provide practitioners and academicians with a realistic roadmap for better SSCM implementation. The created model carefully centres on the Indian material climate; thus, for future degree, scientists may build up the model appropriate for administration enterprises and apply different dynamic strategies to give a superior establishment to SSCM execution in Indian material ventures.

\section{CONCLUSIONS}

This paper presents the enablers identified through a literature review and shows the case study for modelling SSCM enablers. To establish the structural hierarchy of enablers, the enablers are modelled using the Interpretive Structural Modelling technique. The fuzzy MICMAC approach is used to determine each enabler's driving and dependency force.

Identifying the enablers and establishing relationships among them would help the organizations formulate their strategies and understand the behaviour of their influencing factors. By strengthening the factors (enablers) influencing the adoption of a sustainable supply chain, the organizations would be in a better position to increase profitability, reduce harmful environmental effects and boost societal well-being

Fuzzy MICMAC analysis indicated that management engagement, Supplier commitment, Aligning government sustainability policies, Strategic planning with the system are the key enablers having significant driving power. They also have a low level of dependency, making these enablers useful for SSCM implementation. There is no such thing as an autonomous enabler. An autonomous enabler is one with little driving power and little reliance.The enablers are categorized under four different clusters, which will help practitioners develop their strategies for smooth adoption of SSCM within Indian textile industries.

A hierarchical model of SSCMEs is created utilizing ISM and Fuzzy MICMAC approach, which may assist chiefs with recognizing and characterize the basic factors as indicated by the necessities of explicit assembling climate and investigate the immediate and circuitous impacts of every factor on one another. The empowering influences distinguished in this model are really nonexclusive for material assembling concerns. It very well may be made more explicit identified with auto, designing, and interaction ventures for certain changes.

The contributions to the creation of the ISM model and the fluffy MICMAC are due to the decisions made by industry experts and academicians. The judgments, however, are emotional, and any biassing by the experts in passing judgement on the SSCMEs could have a direct impact on the final outcomes. The investigation explicitly cantered around including the empowering influences influencing the fruitful execution of SSCM in material assembling concerns; nonetheless, the created model may reflect various outcomes whenever carried out in a climate other than assembling. In any event, for material assembling concerns, an enormous scope review can be directed to acquire exact outcomes by 
including some influencing factors. Further, primary condition displaying can be utilized by AMOS for building up a profound relationship among info and yield factors with measurable approval.

\section{REFERENCES}

$>$ Amindoust, A. et al. (2012) 'Sustainable supplier selection: A ranking model based on fuzzy inference system', Applied Soft Computing Journal. Elsevier B.V., 12(6), pp. 1668-1677. doi: 10.1016/j.asoc.2012.01.023.

$>$ Bai, C. et al. (2012) 'Evaluating ecological sustainable performance measures for supply chain management', Supply Chain Management, 17(1), pp. 78-92. doi: $10.1108 / 13598541211212221$.

> Bai, C. and Sarkis, J. (2014) 'Determining and applying sustainable supplier key performance indicators', Supply Chain Management, 19(3), pp. 275-291. doi: 10.1108/SCM-12-20130441.

> Beikkhakhian, Y. et al. (2015) 'The Application of ISM Model in Evaluating Agile Suppliers Selection Criteria and Ranking Suppliers Using Fuzzy TOPSIS-AHP Methods', Expert Systems with Applications. Elsevier Ltd, 42(15-16), pp. 6224-6236. doi: 10.1016/j.eswa.2015.02.035.

$>$ Bouchery, Y. et al. (2012) 'Including sustainability criteria into inventory models', European Journal of Operational Research. Elsevier B.V., 222(2), pp. 229-240. doi: 10.1016/j.ejor.2012.05.004.

$>$ Boyer, K. K. and Hult, G. T. M. (2005) 'Extending the supply chain: Integrating operations and marketing in the online grocery industry', Journal of Operations Management, 23(6), pp. 642-661. doi: 10.1016/j.jom.2005.01.003.

$>$ Cai, J. et al. (2009) 'Improving supply chain performance management: A systematic approach to analyzing iterative KPI accomplishment', Decision Support Systems. Elsevier B.V., 46(2), pp. 512-521. doi: 10.1016/j.dss.2008.09.004.

> Carter, C. R. and Easton, P. L. (2011) 'Sustainable supply chain management: Evolution and future directions', International Journal of Physical Distribution and Logistics Management, 41(1), pp. 46-62. doi: 10.1108/09600031111101420.

> Carter, C. R. and Jennings, M. M. (2002) 'Social responsibility and supply chain relationships', Transportation Research Part E: Logistics and Transportation Review, 38(1), pp. 37-52. doi: 10.1016/S1366-5545(01)00008-4.

$>$ Carter, C. R. and Rogers, D. S. (2008) 'A framework of sustainable supply chain management: moving toward new theory', International Journal of Physical Distribution \& Logistics Management, 38(5), pp. 360-387. doi: 10.1108/09600030810882816.

> Chan, F. T. S. et al. (2014) 'An innovative supply chain performance measurement system incorporating Research and Development (R\&D) and marketing policy', Computers and Industrial Engineering. Elsevier Ltd, 69(1), pp. 64-70. doi: 10.1016/j.cie.2013.12.015.

> Chonticha Mathuramaytha (2011) 'Supply Chain Collaboration - What's an outcome? : A Theoretical Model', International conference on financial management and economics, 11, pp. 102-108. Available at: http://www.ipedr.com/vol11/20R10023.pdf\%0Ahttp://www.cnki.com.cn/Article/CJFDTOTAL-JDSY198903018.htm.

> Cochran, J. K. and Roche, K. T. (2009) 'A multi-class queuing network analysis methodology for improving hospital emergency department performance', Computers and Operations 
Research, 36(5), pp. 1497-1512. doi: 10.1016/j.cor.2008.02.004.

$>$ Croom, S., Romano, P. and Giannakis, M. (2000) 'Supply chain management: An analytical framework for critical literature review', European Journal of Purchasing and Supply Management, 6(1), pp. 67-83. doi: 10.1016/S0969-7012(99)00030-1.

$>$ Dubey, R., Gunasekaran, A. and Childe, S. J. (2015) 'The design of a responsive sustainable supply chain network under uncertainty', International Journal of Advanced Manufacturing Technology, 80(1-4), pp. 427-445. doi: 10.1007/s00170-015-6967-8.

> Fayet, L. and Vermeulen, W. J. V. (2014) 'Supporting Smallholders to Access Sustainable Supply Chains: Lessons from the Indian Cotton Supply Chain', Sustainable Development, 22(5), pp. 289-310. doi: 10.1002/sd.1540.

$>$ Gijo, E. V. and Antony, J. (2014) 'Reducing patient waiting time in outpatient department using lean six sigmamethodology', Quality and Reliability Engineering International, 30(8), pp. 1481-1491. doi: 10.1002/qre.1552.

$>$ Kudla, N. L. and Klaas-Wissing, T. (2012a) 'Sustainability in shipper-logistics service provider relationships: A tentative taxonomy based on agency theory and stimulus-response analysis', Journal of Purchasing and Supply Management. Elsevier, 18(4), pp. 218-231. doi: 10.1016/j.pursup.2012.04.001.

$>$ Kudla, N. L. and Klaas-Wissing, T. (2012b) 'Sustainability in shipper-logistics service provider relationships: A tentative taxonomy based on agency theory and stimulus-response analysis', Journal of Purchasing and Supply Management. Elsevier, 18(4), pp. 218-231. doi: 10.1016/j.pursup.2012.04.001.

> Kumar, D. and Rahman, Z. (2015) Sustainability adoption through buyer supplier relationship across supply chain: A literature review and conceptual framework, International Strategic Management Review. Holy Spirit University of Kaslik. doi: 10.1016/j.ism.2015.04.002.

$>\mathrm{Li}, \mathrm{S}$. et al. (2006) 'The impact of supply chain management practices on competitive advantage and organizational performance', Omega, 34(2), pp. 107-124. doi: 10.1016/j.omega.2004.08.002.

> Luthra, S., Garg, D. and Haleem, A. (2014) 'Green supply chain management: Implementation and performance - a literature review and some issues', Journal of Advances in Management Research, 11(1), pp. 20-46. doi: 10.1108/JAMR-07-2012-0027.

$>$ Malviya, R. K. and Kant, R. (2014) 'Identifying critical success factors for green supply chain management implementation using fuzzy DEMATEL method', IEEE International Conference on Industrial Engineering and Engineering Management, 2015-Janua, pp. 214218. doi: 10.1109/IEEM.2014.7058631.

$>$ Meneghetti, A. and Monti, L. (2015) 'Greening the food supply chain: An optimisation model for sustainable design of refrigerated automated warehouses', International Journal of Production Research. Taylor \& Francis, 53(21), pp. 6567-6587. doi: 10.1080/00207543.2014.985449.

> Parlak, A. I. et al. (2012) 'Population behavioral scenarios influencing radiological disaster preparedness and planning', Accident Analysis and Prevention. Elsevier Ltd, 48, pp. 353-362. doi: 10.1016/j.aap.2012.02.007.

$>$ Patil, S. K. and Kant, R. (2014) 'A fuzzy AHP-TOPSIS framework for ranking the solutions of Knowledge Management adoption in Supply Chain to overcome its barriers', Expert Systems with Applications. Elsevier Ltd, 41(2), pp. 679-693. doi: 10.1016/j.eswa.2013.07.093. 
$>$ Qin, F. et al. (2016) 'Supply-chain performance anomalies: Fairness concerns under private cost information', European Journal of Operational Research. Elsevier B.V., 252(1), pp. 170182. doi: 10.1016/j.ejor.2016.01.033.

> Ramudhin, A., Chaabane, A. and Paquet, M. (2010) 'Carbon market sensitive sustainable supply chain network design', International Journal of Management Science and Engineering Management, 5(1), pp. 30-38. doi: 10.1080/17509653.2010.10671088.

> Sajjad, A., Eweje, G. and Tappin, D. (2015) 'Sustainable Supply Chain Management: Motivators and Barriers', Business Strategy and the Environment, 24(7), pp. 643-655. doi: 10.1002/bse. 1898 .

> Tajbakhsh, A. and Hassini, E. (2015) 'A data envelopment analysis approach to evaluate sustainability in supply chain networks', Journal of Cleaner Production, 105, pp. 74-85. doi: 10.1016/j.jclepro.2014.07.054.

$>$ Tay, M. Y. et al. (2015) 'A Review on Drivers and Barriers towards Sustainable Supply Chain Practices', International Journal of Social Science and Humanity, 5(10), pp. 892-897. doi: 10.7763/IJSSH.2015.V5.575.

$>$ Torfi, F., Farahani, R. Z. and Rezapour, S. (2010) 'Fuzzy AHP to determine the relative weights of evaluation criteria and Fuzzy TOPSIS to rank the alternatives', Applied Soft Computing Journal, 10(2), pp. 520-528. doi: 10.1016/j.asoc.2009.08.021.

$>$ Uysal, F. and Tosun, Ö. (2014) 'Selection of sustainable warehouse location in supply chain using the grey approach', International Journal of Information and Decision Sciences, 6(4), pp. 338-353. doi: 10.1504/IJIDS.2014.066633.

> Wilhelm, M. M. et al. (2016) 'Sustainability in multi-tier supply chains: Understanding the double agency role of the first-tier supplier', Journal of Operations Management. Elsevier Ltd, 41, pp. 42-60. doi: 10.1016/j.jom.2015.11.001.

> Wittstruck, D. and Teuteberg, F. (2012) 'Understanding the Success Factors of Sustainable Supply Chain Management: Empirical Evidence from the Electrics and Electronics Industry', Corporate Social Responsibility and Environmental Management, 19(3), pp. 141-158. doi: $10.1002 / \mathrm{csr} .261$.

> Wolf, J. (2014) 'The Relationship Between Sustainable Supply Chain Management, Stakeholder Pressure and Corporate Sustainability Performance', Journal of Business Ethics, 119(3), pp. 317-328. doi: 10.1007/s10551-012-1603-0.

$>\mathrm{Wu}$, Z. and Pagell, M. (2011) 'Balancing priorities: Decision-making in sustainable supply chain management', Journal of Operations Management. Elsevier B.V., 29(6), pp. 577-590. doi: $10.1016 /$ j.jom.2010.10.001.

$>$ Yadav, G. et al. (2019) 'Developing a sustainable smart city framework for developing economies: An Indian context', Sustainable Cities and Society. Elsevier B.V., 47, p. 101462. doi: $10.1016 / j . s c s .2019 .101462$.

$>$ Zaabi, S. Al, Dhaheri, N. Al and Diabat, A. (2013) 'Analysis of interaction between the barriers for the implementation of sustainable supply chain management', International Journal of Advanced Manufacturing Technology, 68, pp. 895-905. doi: 10.1007/s00170-0134951-8.

> Zhang, Z. and Awasthi, A. (2014) 'Modelling customer and technical requirements for sustainable supply chain planning', International Journal of Production Research, 52(17), pp. 5131-5154. doi: 10.1080/00207543.2014.899717. 
> Zhu, Q., Sarkis, J. and Lai, K. H. (2012) 'Green supply chain management innovation diffusion and its relationship to organizational improvement: An ecological modernization perspective', Journal of Engineering and Technology Management - JET-M. Elsevier B.V., 29(1), pp. 168-185. doi: 10.1016/j.jengtecman.2011.09.012.

Zhuang, J., Xu, X. and Cai, G. (2014) 'Discrete dynamic gaming models in supply chain management and project management', Discrete Dynamics in Nature and Society, 2014, pp. 2-4. doi: 10.1155/2014/960239. 